\title{
DELIMITING CENTRAL EUROPE AS A JURIDICAL SPACE: A PRELIMINARY EXERCISE IN CRITICAL LEGAL GEOGRAPHY
}

\begin{abstract}
The aim of the present paper is to contribute to the on-going discussion, both in legal theory and in comparative law, concerning the status of Central Europe and its delimitation from other legal regions in Europe, notably Romano-Germanic Western Europe but also Eastern Europe and Eurasia. The paper adopts the methodological perspective of critical legal geography, understood as a strand of critical jurisprudence laying at the interstices of spatial justice studies, critical geography, comparative law, sociology of law and legal history. The paper proceeds by identifying the notion of Central Europe with reference to a specific list of countries, then proposes a number of objective criteria for delimitng Central Europe and applies them in order to highlight the difference between Central Europe and other adjacent legal regions. Following that, the paper enquires as to whether Central Europe should be deemed to be a 'legal family', a 'legal union' or simply a 'legal space' or 'space of legal culture'.
\end{abstract}

Keywords: critical jurisprudence, critical legal geography, legal theory, comparative law, legal families, legal taxonomy, Central Europe.

\section{INTRODUCTION}

Central Europe as a legal notion emerged in the 1990s, when the former EastWest divide in Europe disappeared with the dismantlement of the Soviet bloc.

The present intervention is subtitled as a 'preliminary exercise in critical legal geography'. It is preliminary in the sense of providing an outline towards further, in-depth research based on a broad range of legal materials. Critical legal geography, in turn, is understood here as a strand of critical jurisprudence (critical legal theory) placed at the insterstices of critical geography (Best 2009; Berg 2010), spatial justice studies (Pirie 1983; Philippopoulos-Mihalopoulos 2013), as well as (comparative) legal history and comparative law. Its aim is to reflect critically upon geographical categories used in legal discourse. ${ }^{1}$ As such, it encompasses the field of legal taxonomy (the discourse of comparative law concerning legal families) but

*University of Amsterdam, Centre for the Study of European Contact Law, r.t.manko@uva.nl

${ }^{1}$ I am using the notion of critical legal geography not in the sense of linking geographical features (e.g. islands, mountains, rivers, forests, deserts etc.) with legal culture (in some causal manner), but rather in the sense of the study of the spatial (geographical) dimensions of legal culture. In other words, 'geography' denotes here the socially constructed legal geography, and not the physically existing 'natural' geography (in the sense of the shape of the terrain). 
is broader. Critical legal geography enquires about legal transfers historically and today, about the spatial dimension of law (e.g. the coexistence of different legal systems within one state ${ }^{2}$ or the extension of legal systems beyond one state ${ }^{3}$ ), including the relation between specific features of spatiality and the legal system (e.g. as argued by Eurasian legal theorists).

As part of critical theory, and in line with its links to critical geography and spatial justice studies, critical legal geography, as proposed here, is predominantly concerned with unmasking violence and domination (of any form) and promoting emancipation (i.e. resistance to violence and domination, leading to the liberation of the opressed). In casu, the focus will be on a specific region: Central Europe (as defined in section 2), which - on account of its peripheral status - has been subject to domination (in casu - legal). I contend that this domination is spatially determined: for various reasons of historical development (political, economic, military etc.) and contemporary predicament, the countries situated in this region have been exposed to forms of external domination which, in the legal realm, takes the form of being a recipient of legal transfers, rather than an originator of them (Mańko 2017a). It is a structural feature of legal geography.

The present paper develops ideas raised in earlier publications (Mańko, Cercel, Sulikowski 2016; Mańko, Škop, Štěpáníková 2018) aiming at the elaboration of more precise criteria for identifying Central Europe as a specific legal space, capable of articulating its interests and making an actual move towards its emancipation. Most importantly, the paper proposes a catalogue of six criteria (in section 4.2) which can be used as criteria of delimitation of Central Europe from adjacent legal spaces. A tentative application of those criteria is undertaken in section 4.4. Furthermore, the paper develops the ideas present in the earlier publications by considering more closely the relation between the concepts of Central Europe (section 2) and Central and Eastern Europe (section 3), and refers back to this possible alternative when summarising the results of the application of the criteria of distinguishing. Finally, in contrast to an earlier seminal paper (Mańko, Škop, Štěpáníková 2018), the present one does not unequivocally argue in favour of a Central European Legal Family but instead raises two alternative concepts: that of a 'legal union' and 'legal space' (section 5).

In methodological terms, the paper belongs to the metadiscourse of critical legal geography, as defined above. It seeks, above all, to set the framework for

${ }^{2}$ A prime example from Central Europe is the coexistence, between 1918 and 1946, of five distinct legal systems in the Republic of Poland (French-Polish, Russian, German, Austrian and Hungarian law). Examples from outside the region include the continued existence of a distinct Scottish legal system in the UK or the specificities of Lousiana law within the US (as a Civil Law jurisdiction within a predominantly Common Law country).

${ }^{3}$ As in the case of wholesale receptions, such as that of French law during the period of Napoleonic wars which - notably - survived the fall of Napoleon and continued in force, in western Germany (the Rhine Provice), until 1900 and in central Poland - until 1946. 
discussion on the legal identity of Central Europe by putting forward and testing workable criteria allowing to outdifferentiate this legal space from others, as well as to open a space for discussion on the nature of this legal region (legal family, legal union, legal space). Hence, the object of the paper is to put forward a rational ramification for further research, and in particular to encourage a broadly conceived empirical analysis of the legal cultures of Central European countries in the hope of positively verifying the hypotheses put forward in this and earlier papers.

\section{DEFINING CENTRAL EUROPE}

If Central Europe is conceived of as a juridical space, two questions must be answered: firstly, what areas should be treated as falling within the category of Central Europe and secondly, from what areas should Central Europe be distinguished from. The first question is more difficult and will therefore be addressed beforehand. Among critical legal theorists from Central Europe the prevailing conception of Central Europe is that of former socialist states (including former USSR republics) which have joined the European Union (Mańko, Cercel, Sulikowski 2016; Mańko, Škop, Štěpáníková 2018). Admittedly, this is a somewhat arbitrary category, but on the other hand it is highly functional with regard to contemporary legal culture. There is no doubt that the two delimiting factors - former socialist legal system and current membership in the EU - play an enormous role in the legal culture of each country. The former socialist legacy creates numerous challenges, from transitional justice to socialist survivals in legal culture, especially judicial mentality, which have been comprehensively described by Zdeněk Kühn $(2004,2011)$ and Alan Uzelac (2010). EU membership, on the other hand, means a duty to receive massive legal transfers and to subject oneself to the jurisdiction of the Eureopean Court of Justice, an arguably activist court which, through its case-law, seeks to influence the legal culture of the EU Member States with view to their uniformisation. Thus defined, the category of 'Central Europe' would encompass (in alphabetical order): Bulgaria, Croatia, Czechia, Estonia, Hungary, Latvia, Lithuania, Poland, Romania, Slovakia and Slovenia. It would be a dynamic category, i.e. the accession of new Member States (e.g. Albania or Northern Macedonia) or leaving the EU by some country from the region would affect the category. Undoubtedly, joining or leaving the EU has a tremendous impact upon legal culture and cannot be ignored by legal geography as an important factor. Nonetheless, defining Central Europe along these lines means that former socialist countries which are not EU members are not included (specifically: Albania, Belarus, Bosnia and Herzegovina, Moldova, Northern Macedonia, Russia, Ukraine). If we treat the concept of 'Europe' more broadly, i.e. extending also to Transcaucasia, the list of exluded countries encompasses also the commonly 
recognised: Armenia, Azerbaijan and Georgia. ${ }^{4}$ A common denominator of the region is the communist past. As Cosmin Cercel $(2018,199-200)$ rightly underlines,

Either as a matter of transitional justice, constitutional reform or simply political debate, the communist legacy is a recurrent trope through which the countries of the region are identified. [...] Of course, such a process is laden with traces of cultural representations that reflect not only the East-West divide in geographical imaginaries, but also reenactments of Balkanism, or the center-periphery dialectics. Indeed, behind the signifier »communism « attached to Central and Eastern Europe, one can easily find and filter residues - if not of a colonial gaze, at least those of a specific discourse positing the West as the centre and norm.

Importantly, this approach to the notion of Central Europe means excluding countries which formerly would have been regarded as 'Central Europe' or Mitteleuropa, notably today's Austria and Germany, which cannot be described as post-communist states. However, the change of Germany's borders after 1945 meant that it lost its Central European territories (Pomerania, Silesia, West and East Prussia) to Poland and Russia. Whilst the former German Democratic Republic (GDR) was, during the period of its existence (1949-1990) regarded as part of Eastern Europe (the Soviet bloc), its integration into the Federal Republic of Germany, and notably the extension not only of the West German legal system, but also the West German legal apparatus (judiciary, academia) onto the former East German territory (removal of judges, prosecutors, law professors, etc.) meant that - even if geographically the eastern part of Germany could be regarded as Central Europe, in terms of legal culture it became (more or less forcibly) Westernized, and reunited Germany as a single state cannot be described as 'post-communist'.

Concerning the second problematic case, namely Austria, it should be stated that although in strictly geographical and historical terms Austria and especially its predecessor, Austro-Hungary, was a Central European country, since 1945 the Republic of Austria has clearly drifted away in the direction of Western Europe. Nonetheless, as all categories used by critical legal geography need to be dynamic, the situation and its evolution need to be closely observed as the state of affairs may change.

On the eastern flank the category of Central Europe in the aforementioned sense excludes Russia, Belarus and Ukraine - former Soviet republics. Whilst Russia's status as part of Eurasia and Eastern Europe is rather undisputable in historic and geographical terms, the status of Belarus and Ukraine is open to discussion. However, given the current orientation of the Republic of Belarus, remaining closely linked to the Socialist Legal Tradition, and its membership in the Eurasian Economic Union rather argue in favour of its inclusion with Eastern Europe and Eurasia, than Central Europe. As regards Ukraine, it should be emphasised that its legal culture is, at the moment, in a state of dynamic

${ }^{4}$ For reasons of brevity, I am not discussing here self-proclaimed states whose status is disputed and which are recognised only by some other countries, but are not UN members. 
transformations the outcome of which can be decisive with regard to its classification as part of Central Europe or Eastern Europe/Eurasia. Clearly, prior to 2014, when Ukraine was a member of the Eurasian integration structures, it was, alongside Russia and Belarus, a post-Soviet, Eastern Europen/Eurasian legal culture. Currently, in terms of legal culture, Ukraine is a liminal region between Central and Eastern Europe. Mutatis mutandis, these remarks can be applied to the Republic of Moldova.

Finally, some remarks must be made concerning the Baltic States - Lithuania, Latvia and Estonia. They do share with Central Europe a socialist past (and specifically, the fact of being Soviet Republics between 1940 and 1990) and have juridico-cultural links with Poland (e.g. the Polish-Lithuanian Commonwealth, and specifically the fact that the region of Livonia (Inflanty) was part of that Commonwealth). However, especially with regard to Estonia, its links to the Nordical legal family cannot be overlooked. Therefore, it can be regarded as a liminal region within Central Europe and the situation needs to be more closely observed over time.

On the southern flank, the Balkan states of Albania, Bosnia and Herzegovina, Serbia and Northern Macedonia can be regarded as liminally belonging to Central Europe, although due to their non-integration with the EU, their legal cultures are not exposed to the same stimuli as those of Poland, Czechia or Bulgaria.

In economic terms, Central Europe is definitely a periphery. As Damjan Kukovec explains:

The centre countries or regions are those with a much higher gross domestic product (GDP) per capita than the regions of the periphery; they invest more money in research and development and have the best universities; they have more capital and more ingoing and outgoing foreign direct investment (FDI). Their actors, products and services have more prestige. [...] Generally, companies of the centre find themselves higher in European and global production chains. The centre exports final products and is the seat of powerful corporations and law firms. Countries of the centre are, for example, Germany, France, the Netherlands, Austria, Sweden, Finland and the United Kingdom. The periphery has much weaker industry and a less efficient agricultural sector. It has no (or very few) brands known beyond its borders. Non-branded companies typically earn lower margins and are constantly at risk of being undercut by cheaper rivals. [...] Regions of the periphery have a lower GDP per capita, and the actors, products and services from the periphery have much less prestige. They often produce semi-final products or final products for a brand of the centre. Generally, companies of the periphery find themselves lower in European and global production chains. The wages are lower than in the centre, and often (with the exception of the European south) the life expectancy is lower. Countries of the periphery are, for example, Hungary, Portugal, Greece, Bulgaria, Cyprus, Latvia, Poland, Slovenia and Estonia (Kukovec 2015, 408-409).

This peripheral status - as an economic notion - is closely linked to peripherality in other terms, especially political, social and juridical. Without aiming at explaining the causal links between various forms of peripherality, assuming that the juridical enjoys a relative autonomy from the economic (Collins 
1982), it seems feasible that juridical peripherality can be, at least partly, remedied within juridical discourse itself (Mańko, Škop, Štěpáníková 2018, 23-24).

\section{CENTRAL AND EASTERN EUROPE (CEE) AS AN ALTERNATIVE CATEGORY?}

Given the geographical and juridico-cultural issues entailed by the category of Central Europe as presented above, an alternative spatial category which could be taken into account is that of 'Central and Eastern Europe'. This broader category would, essentially, encompass the entirety of Central Europe and those countries which are located within geographical Europe sensu largissimo but do not belong to Central Europe. Central and Eastern Europe would, therefore, comprise also Russia, Belarus, Ukraine, Moldova, Georgia, Azerbaijan, Armenia, Serbia, Northern Macedonia, Albania, Bosnia and Herzegovina.

For some purposes, such a category may be useful, but for others it can seem more problematic. Specifically, Russia is leading the legal integration of the former Soviet space in the form of the Eurasiatic Economic Union. On the other hand, Russia remains a member of the European Convention on Human Rights and remains subject to the jurisdiction of the Strasbourg Court, which leads to interactions between its legal system and the Western European tradition of human rights law, developed in the post-World War II period (Mälksoo, Benedek 2017). Countries such as a Serbia, Bosnia and Herzegovina, Albania, Northern Macedonia, Montenegro and Moldova share with Central Europe a socialist past and a capitalist present, hence many of the legal problems encountered there are similar (e.g. property transformation, transitional justice), despite the lack of EU membership. Also historically these regions were closely linked to Central Europe (e.g. today's Republic of Moldova was part of the Kingdom of Romania, Bosnia and Herzegovia as well as the the northern part of today's Republic of Serbia was part of Austro-Hungary, not to mention the seven decades of existence of the Yugoslav state, extending from Slovenia to Macedonia, whose legacy in the field of legal culture cannot be overlooked.

\section{DELIMITING CENTRAL EUROPE VIS- $\grave{A}-V I S$ ADJACENT LEGAL SPACES}

\subsection{Central Europe and former empires}

In order to delimit Central Europe vis-à-vis neighbouring legal spaces, two elements must be specified beforehand: firstly, the legal spaces with regard to which such a delimitation is to take place and secondly, the criteria for delimitation. For the present purposes, a hybrid notion of Central Europe will be 
applied, encompassing Central Europe as defined above and Central and Eastern European states with the exclusion of Russia which, for the present purposes will be treated as Eurasia. Historical factors also support this hybrid approach - if Central Europe is conceived of as a space subject to the domination of empires (German, Austrian, Russian and Ottoman), the former empires themselves cannot be treated as part of notion of Central Europe. This is particularly justified by the phenomenon of legal transfers, a key notion for critical legal geography. As it will be explained further on, such transfers usually move from the metropolis towards the territories subject to the Empire's rule, and not vice versa. On the other hand, the four empires which have, in the past, dominated Central Europe, can be themselves classified in terms of centre-peripheries as belonging to the Centre (German Empire), the Semi-Periphery (Austrian Empire) and Periphery (Russian and Ottoman Empires). As it will become clear later on, the semi-peripheral and peripheral status of empires dominating Central Europe had an impact upon the dynamic of legal transfers, with empires such as Russia and later the Soviet Union acting both as a recipient and as a donor of legal transfers.

\subsection{Criteria of delimitation}

A second question which needs to be addressed as a preliminary issue is the catalogue of criteria for delimitation. The following seem to be particularly helpful: 1) the dynamic of legal transfers; 2) institutional continuity; 3) legal continuity; 4) legal style; 5) legal ideology; 6) the social role of law. Each criterion will be explained in more detail.

Ad 1. The concept of the dynamic of legal transfers refers to the fact whether a given state (jurisdiction, territory) has been the originator or recipient of legal transfers, in the past and today (Watson 1993; Krzynówek 2003; Ajani 2006; Husa 2015). Furthermore, apart from the aspect of direction (incoming or outgoing legal transfers) one should take into account their modality and differentiate between voluntary legal transfers (receptio voluntaria) and forced legal transfers (receptio necessaria). The latter are of particular concern for critical legal theory, as they imply an act of violence. This violence can be military, political or economic (reception of foreign law as a conditionality).

It should be added here that critical legal theory is concerned with various forms of violence. For instance, Lidia Rodak $(2015,133)$ identifies five forms of violence: psychological, symbolic, structural, hermeneutic and aesthetic. Martin Škop (2015) adds to this also linguistic violence. In turn, Wioletta Jedlecka and Joanna Helios (2017, 15-30) identify physical, psychological, sexual, economic, latent, structural, instrumental and symbolic violence. The links between legal transfers and violence certainly require further theoretical and empirical research, nonetheless it can be prima facie pointed out that such transfers may involve especially symbolic violence (degradation of the local legal community), linguistic 
(a foreign legal transfer arrives in a foreign language, and the local implementation is only a translation, referring back to the original); aesthetic (if the legal transfer follows a different aesthetic than local law, for instance a codification $v s$ customary law, or technocratic law $v s$ traditional civil law); economic (if a legal transfer is imposed as a conditionality); structural (if the legal community of the donor becomes epistemologically privileged); possibly also heremeutic (if the legal transfer distorts interpretive processes in the recipient legal community). Furthermore, if legal transfers lead to legislative inflation (Chmielnicki 2012) and instrumentalisation of law (Sitek 2008, 66-78) in a technocratic fashion (Ziętek 2012; Mańko 2017c), this can also have negative impacts upon the recipient legal culture.

On the other hand, critical legal theory cannot overlook the fact that a legal transfer, even if it is the effect of violence (military and economic) and exerts violence (especially vis-à-vis the recipient legal community and its legal culture), can nonetheless be emancipatory towards certain social groups, removing opression and violence, especially if it introduces more progressive rules than those found originally in the given recipient legal system (cf. Mańko 2008). A critical study of legal transfers in Central Europe, particularly in the 19th and 20th century, cannot overlook this aspect.

Ad 2. The concept of institutional continuity refers to the institutional framework of the juridical, such as the courts, the prosecution service, the legal professions (attorneys, notaries), both in terms of their personal substratum and in terms of legal arrangements (rules in force). Continuity encompasses especially an on-going tradition, transmitted by education and professional apprenticeship, whilst discontinuity implies creating a new profession from scratch. Institutional continuity in this sense should be distinguished from the continuity of legal institutions (Rechtsinstitute), i.e. functionally interlinked, relatively coherent sets of legal norms (Renner 1976, 75; Ziembiński 1980, 34; Sulikowski 2007, 35, 61; Mańko 2016a, 13-14).

Ad 3. The concept of legal continuity refers here to the on-goingness of the positive law, including its structure, fundamental principles, conceptual framework, and individual institutions and rules (Mańko 2018a). The notion of legal continuity, understood in this way, should be differentiated from the social function of legal institutions (Mańko 2018a, 118), which is treated for our present purposes as a different criterion.

Ad 4. The concept of legal style is understood here with reference to Zweigert and Kötz $(1996,68-72)$ but in a somewhat more narrow meaning, ${ }^{5}$ focusing especially on the the predominant and characteristic mode of legal thought,

${ }^{5}$ I would like to thank the anonymous reviewer for drawing my attention to the difference between the scope of the notion of legal style used in my paper and the broader understanding by Zweigert and Kötz (1996). 
acknowledged sources of law and prevailing modes of legal reasoning (Mańko, Škop, Štěpáníková 2018, 15). Therefore, such elements as historical development of the legal system or legal ideology are singled out as separate criteria.

Ad 5. The concept of legal ideology, mentioned already above, encompasses the prevailing views of lawyers on the role of law and their own role within the legal community and society at large. As such it is strictly connected both to legal style and to the final category of the social role of law.

Ad 6. The concept of the social role of law relies on sociological categories according to which the entirety of social life is differentiated into certain systems (Luhmann) or institutional worlds (Berger and Luckmann), one of which is law (or 'the juridical'). This criterion refers, firstly, to the outdifferentiation of the juridical from politics and the economy (or other systems, such as custom or religion) and secondly, in the case of its outdifferentiation, to the relation between the juridical and such systems (e.g. whether the economy is subject to the rule of law, or the subject to the rule of economy or to political decisions).

\subsection{Neighbouring legal spaces}

In the following analyses, I will apply these six criteria to the legal spaces from which Central Europe needs to be delimited in order to be constituted as a distinct legal space. These legal spaces can be conceived in various ways. On the one hand, it is possible to refer to the concept of legal families and speak here of the following: 1) Common Law Family; 2) Nordic/Scandinavian Legal Family; 3) Romanic Legal Family; 4) Germanic Legal Family; 5) Eurasian Legal Family. The Romanic and Germanic can also be merged as the Romano-Germanic Legal Family. However, within that region - comprising continental Europe - one could also outdifferentiate Southern European (Mediterranean) legal systems, and treat them as a distinct category (i.e. Italy, Spain, Portugal, Greece). Such detailed comparisons would undoubtedly be useful, however for our present purposes of a merely preliminary enquiry into the issue, it seems more useful to refer jointly to the Romano-Germanic legal family.

\subsection{Application of the distinctive criteria (a preliminary tentative)}

A complete and comprehensive application of the six distinctive criteria developed above (dynamic of legal transfers, institutional continuity, legal continuity, legal style, legal ideology and social role of law) would definitely require a large-scale comparative research project, involving researchers from various jurisdictions and representing various specializations (private lawyers, administrative lawyers, constitutionalists, criminal lawyers, to name but the most important ones). Therefore, what follows below is a merely preliminary tentative sketch, which - hopefully - will eventually inspire a fully-fledged research endeavour by a team of competent and dedicated scholars. 
Starting from the first criterion, namely the dynamic of legal transfers, it should be emphasised that at least since the 19th century, i.e. for over 200 years now, Central Europe has been exclusively a recipient of legal transfers. There is no meaningful example of a Central European legal system acting as a donor of legal institutions towards other countries. This specific feature contrasts Central Europe not only with Western Europe, both Romano-Germanic and Common Law, which have a long track record of being donor legal systems, ${ }^{6}$ but also with Eastern Europe - Russian and later Soviet law, although relying to a large extent on legal transfers from Germany, were themselves an object of transfers to Central Europe. To name but a few examples, one can mention the institution of supervisory instance or the broad powers of the prosecutor which, originating in Russian/Soviet law, were transferred to Central European legal systems. There seem to be no examples of reverse transfers, i.e. of a Polish, Czech or Romanian legal institution which was transferred to Soviet law. In general, there also seems to have been little internal transfers within Central Europe, although there are notable examples of cooperation, such as attempts at unifying Central European (in casu Slavic) legal systems, commenced in the 1930s, stopped by World War II (Jędrejek 2001, 66), and the well-known Polish-Czechoslovak cooperation on elaborating a joint Family Code (Fiedorczyk 2009; Fiedorczyk 2011; Fiedorczyk 2012; Fiedorczyk 2013). These examples suggest a different approach to the transfer of legal models, more collaborative, balanced and respectful than the West-to-East flow of legal transfers, known in the 19th century and on-going also today, in an only slightly modified form (Mańko 2017a). One could only express the desire for such efforts to be restarted once again within our region, especially after the mainly Western European efforts for elaborating a European Civil Code have been aborted.

Turning to the second aspect of the dynamic of legal transfers, namely their modality, one should emphasise that in Central Europe there have been both periods of voluntary transfers and periods of forced transfers, and sometimes both coincided at the same time. For instance, when in the 19th century Bulgaria received Italian contract law, it was definitely not imposed by force (Bulgaria was not occupied by Italy, the Bulgarian king was German, not Italian). Hence the choice of Italian law can prima facie be treated as voluntary. The same can be said of the reception of French and Austrian law in Moldavia in the early 19th century (Bocşan 2006: 36).

However, when French law was introduced in 1808 in the Duchy of Warsaw, this was a receptio necessaria - the Polish legal and political elites in the Duchy were not given any choice. Likewise, the reception of French legal models in 19th century Romania (Diamant, Luncean 1986, 100) can be treated as voluntary, whilst the introduction of the ABGB in the Kingdom of Croatia - involuntary, imposed by

${ }^{6}$ Apart from the well-known reception of German, French and Austrian law, one should mention inter alia the reception of Italian law of obligations in Bulgaria in 1893 (Jędrejek 2001, 66). 
the Austrians (Čepulo 2006, 58). There is no necessary link between the fact that a given Central European country was an idependent state at the time of reception and the modality of reception, although having an independent country certainly is conducive towards voluntary legal transfers. However, this need to always be the case. For instance, if we compare the transfer of the Franco-German institution of unfair contract terms, we will note that it was a receptio voluntaria for the then 12 EU Member States (who adopted the Unfair Terms Directive in Council), but a conditionality of membership - and hence receptio necessaria - for Poland, Hungary or later Romania and Croatia (cf. Micklitz 2015, 5). Such forced legal transfers may, not unexpectedly, lead to a resistance from the legal community, as was, for instance, initially the case with the Unfair Terms Directive in Poland (Mańko 2012).

On the other hand, the legal elites of the Polish People's Republic - despite the limitation of Poland's sovereignty by the USSR - enjoyed quite a large margin of discretion when chosing certain legal models, and did not always rely on direct legal transfers from Soviet law. In fact, the situation changed over time, and whilst in 1950 such transfers were introduced almost directly, especially in civil procedure (Mańko 2007), after 1956 many solutions were either original Polish ones (as the cooperative member's in rem right to an apartment - Mańko 2015) or highly modified ones, only loosely inspired by Soviet law (as the perpetual usufruct - Mańko 2017b).

Discussing the dynamic of legal transfers, one should also take into account not only private law (which traditionally has been the prime object of interest of comparative lawyers), but also public law. It should be emphasised that, for instance, constitutional justice has been, in Central Europe, an object of reception, mainly from Germany, as has also been the case with various institutions of administrative law, such as agencies (Bieś-Srokosz 2017).

Turning to the second criterion, namely institutional continuity, one cannot but emphasise a striking institutional discontinuity, which seems to have been a feature of Central Europe for the past two centuries. This was linked with the supression of earlier forms of statehood and creation of new ones, with abrupt cutoffs. One could mention here the fall of the Polish-Lithuanian Commonwealth in 1795 and the introduction of Prussian, Russian, Austrian and subsequently also Polish-French administrations, including justice systems, in the 19th centuries, followed by the creation of the Republic of Poland in 1918, its fall in 1939 and the subsequent re-creation, largely from scratch, of People's Poland starting from 1944, and so forth. This is in sharp contrast to the West, where insitutional continuity has been generally strong, at least since the beginnings of the 19th century.

The third criterion, namely legal continuity is also an example of abrupt changes ocurring over the past 200 years almost continuously. This contrasts the region especially with Western Europe where continuity and evolutionary reforms either ocurred since the Middle Ages (Common Law Family) or at least since the era of the Grand Codifications (Civil Law Family). But even the Codes did not 
always bring about abrupt changes, and for instance the German Civil Code of 1896 is commonly deemed to be a restatement of the Pandectist School, rather than a revolutionary change in private law (cf. Zimmermann 2006).

\section{CENTRAL EUROPE: LEGAL FAMILY, LEGAL UNION OR LEGAL SPACE?}

In light of the foregoing it is justified to pose the question as to how can Central Europe be addressed within the discourse of critical legal geography and, more broadly, space-oriented jurisprudence (such as the discourse of legal taxonomy proper to comparative law). The first category which comes to our mind is that of a 'legal family' (in German referred to as 'Rechtskreis', literally - 'legal circle'). This category was elaborated in 20th century comparative law, in particular by Zweigert and Kötz, (Zweigert, Kötz, 1987), as well as René David (David, Brierly 1968), and can be said to be an established category of comparative law. The category of legal tradition, elaborated by John Henry Merryman (Merryman 1969) and later by H. Patrick Glenn (Glenn 2010), although termed differently, is in fact identical to that of legal family which can be easily discovered by comparing the criteria divisionis put forward by Merryman and Glenn on the one hand, and those put forward by Zweigert, Kötz and David, on the other. What is common to all these notions, despite certain differences, is the emphasis put on the genetic aspect - legal families/traditions essentially share the same historical roots which shape their legal culture in contemporary legal life.

Looking upon Central Europe in this perspective we immediately notice the problematic character of the genetic approach: the historical roots of Central Europe are actually quite diverse. Czech law flows from Austrian law, Romanian law from French law, and Polish law is a mix of elements flowing from German, French, Swiss and partly Austrian law. The genetic criterion is, therefore, somewhat problematic in Central Europe. It can also be criticised for being a formalist criterion, oriented towards the historical roots of legal institutions, and overlooking the current legal life, and the actual features of 'law-in-action', i.e. the living law, rather than its historical roots. The popularity of the genetic criterion can be easily explained: in the West, the main difference has been between the countries which received Roman law (the Civil Law tradition) and those which did not (the Common Law tradition). Comparative law in the West was mainly focused on the Civil Law vs. Common Law divide, and the criteria elaborated by Western comparative lawyers naturally looked for the main criterium divisionis between the UK and 'the Continent' (France, Germany). That criterium was the reception or non-reception of Roman law.

However, in Central and Eastern Europe things look differently, also from a historical perspective. The region never received Roman law, although it had a certain influence due to the fact of being taught, for instance at the Jagiellonian University. On the other hand, in the Eastern European countries subject to the 
Byzantine tradition and later to non-European domination (Mongolian, Ottoman), if Roman law had any influence, it was, firstly, in the form of Byzantine law, and secondly, there was no influence of Western Canon Law (of the Latin rite), which - as it is well known - had a very strong impact upon the development of Western European laws, including not only the famous Roman-Canon procedure, but also various elements of private and public law.

All in all, the impact upon the genetic aspect can be deemed as not as significant in Central and Eastern Europe as it is in Western Europe, where the Civil Law vs. Common Law division is strongly rooted in rather distant (i.e. medieval) legal history. Therefore, the notion of legal family/legal tradition, if it is to be understood along the lines of David, Zweigert, Kötz, Merryman and Glenn, could be less workable with regard to Central Europe than it is with regard to Western Europe. It is at this point that the concept of a 'legal union' - fashioned along the lines of 'linguistic union' - could come in handy. As Bulat Nazmutdinov (2019) writes in the present issue of Folia Iuridica, the concept of a legal union was developed in the Eurasian legal theory of the 1920s and 1930s as an attempt to explain the legal similarity of Eurasian legal systems which, despite different roots, have become assimilated to each other on account of long-term coexistence within one space (the Eurasian one). I think that this concept, first developed with regard to Eurasia, can also be applied, mutatis mutandis, to Central Europe. In essence, using the concept of a legal union instead of a legal family/tradition moves the emphasis from the roots of legal systems (i.e. their more distant history) towards their long-term coexistence within a given, common space. Thus, applying the notion of a legal union to Central Europe, one could argue that despite their different origins (Romanic, Germanic, Scandinavian, etc.) the legal systems of Central Europe have been coexisting together within one legal space, initially within the socialist bloc, and currently within the European Union, which has led to their progressive assimilation.

Finally, the concept of a 'legal space' could be used with regard to Central Europe, intended as a neutral yet capacious term, leaving aside the question of legal families, legal traditions or legal unions, and emphasising the currently present similarities and interactions. The notion is frequently used in Italian legal literature (spazio giuridico), especially in connotation to European and global processes of legal integration (hence concepts of 'spazio giuridico europeo' and 'spazio giuridico globale'). Importantly, these notions abstract from legal families or legal traditions and focus on the on-going interactions between legal orders. The adoption of the concept of legal space with regard to Central Europe must, however, be undertaken cum grano salis. The legal space of Central Europe is predominantly a space of a common legal culture and a common legal mentality, and not so much a space of actual juridical interactions as opposed to the legal space of the EU or the global legal space (for want of regional forms of integration in Central Europe). Therefore, it would be more justified to speak of Central Europe as a 'space of legal culture' (Mańko, 
Škop, Štěpáníková 2018), rather than a juridical space (spazio giuridico) in the strict sense. As such, Central Europe is, objectively speaking, a legal-cultural space in itself (not conscious of its idenity), and the task of critically oriented jurisprudence in the region is to transform it into a legal space for itself, i.e. self-conscious of its distinct legal identity. Various academic networks, which have emerged in the region in the last years, can be instrumental to this end, especially the Central and Eastern European Network of Legal Scholars - CEENELS (Zomerski 2015, 2018; Szymaniec 2018) as well as, to a certain extent, the Central and Eastern European Network of Jurisprudence - CEENJ (Mańko 2018c) and the International Workshops on Law and Ideology which have had a strong Central and Eastern European dimension (Mańko, Kauczor, Zomerski 2015; Rakoczy 2015; Mańko 2018b), as well as, to a certain degree, also the annual CEE Fora (Gárdos-Orosz, Fekete 2017).

\section{CONCLUSIONS}

Central Europe is a space ridden by violence: symbolic, military, economic, political and, finally, juridical. Its various parts, extending from Northern Macedonia and Bulgaria in the south, to Estonia and Latvia in the north, have been subjected to the more or less 'enlightened' rule or at least domination of various empires, ranging from the Ottoman, through the Habsburg, intermittently French, Prussian/German and finally Russian and Soviet. Degrees of political and economic dependence varied, but the region's peripheral status, established already in the 15th-16th century, was only emphasised by its political subjection to foreign masters. This could not have remained without influence upon legal culture. One of the most striking features of Central Europe is that it has been, at least for the last 200 years, an arena of incoming legal transfers, many of which were forced and involuntary, but at the same time was not an originator of legal transfers. Legal transfers always represent an intake of foreign law, and if they are forced, they also represent an act of violence upon the local legal community and society at large. Furthermore, the region is characterised by a very high level of legal discontinuity: the laws in Central Europe had been modified much more often and much more profoundly than has been the case in the West. Legal insitutions - the professional juridical apparatus - have also changed rather frequently, although after 1989 a larger degree of continuity was generally maintained. The prevailing legal style and legal ideology in the region have been described as hyperpositivist or ultraformalist, but at the same time the place of law in society has generally been different than in the West. The current phenomenon described as 'retraditionalisation' of constitutional law (Medushevsky, 2018), observed both in Central and in Eastern Europe, can be seen as a rejection of a legal transfer which, although formally voluntary, was in fact involuntary (as it was a conditionality of joining 'the West'). 
What is important from the perspective of critical legal theory - in casu critical legal geography - is, first of all, to draw attention to the violence, including symbolic, which has been inflicted upon Central Europe, in a sense, constituting it as a legal space. What is important is to go beyond the mere statement about 'modernisation through transfer', but show how the massive intake of foreign legal models, voluntary or not, impacted upon the prestige of the local legal community (as inferior to the West) and on the perception of law by society (as something foreign). This could be a key factor explaining the current phenomenon of 'Rule of Law backlash' - if the entire 'Rule of Law' setup is a foreign legal transfer, experienced by society and even by many lawyers as foreign and imposed, this could explain a relatively low degree of acceptance by the legal community and society. A second element from the above considerations which could have an explanatory potential with regard to the said 'backlash' is the place of law in society (both actual and perceived).

A second aspect crucial from the perspective of critical legal geography conceived as a unity of theory and praxis is the self-constitution of the region as a legal space distinct both from the West and East. Constructing such an identity may not be easy, but the efforts have begun. The stakes are high. As Kukovec (2015, 427-428) forcefully argues:

A grid of legal thinking on the centre-periphery axis is thus needed. Only then does the space for thicker politics, which entails higher political engagement, open up. [...] The legal discourse, the currency in which interests are discussed, excludes people on the periphery. [...] The outlook, the mindset of the European legal profession, is one of the centre. The wrong suffered by the actors in the periphery is often not signified in the idiom. Workers and companies from the periphery can participate in the discourse and somehow become plaintiffs and defendants, but this does not mean that they cease to be victims. Their aspirations are weak and their harms are often not actionable [...]

A juridical articulation of Central Europe's interests, not only in the short term (which Kukovec seens to focus his attention on), but also in the long term (for instance, concerning the development of adequate legal institutions, principles, suited for the region), can be possible only if the region's legal identity is asserted. In this paper I tried to show that, on the basis of a set of objective criteria, Central Europe can be persuasively differentiated both from Western and from Eastern Europe. This approach can be a first step towards building a Central European legal identity which, in turn, could help to combat the region's juridical peripherality and redeploy the energy of the region's legal communities from adapting to the constant influx of foreign legal transfers towards the innovative elaboration of original legal institutions, suited to the needs of Central Europe. Instead of waiting for the West to come up with a solution that can later be copypasted into Central European laws, our jurists should rather try to find solutions themselves, returing to the good traditions of legal cooperation within the region. 


\section{BIBLIOGRAPHY}

Ajani, Gianmaria. 2006. Sistemi giuridici comparati. Torino: Giappichelli.

Berg, Lawrence. 2010. "Critical Human Geography". In Encyclopedia of Geography. Edited by Barney Wharf. SAGE Publications. https:/www.academia.edu/2044691/Critical_Human_ Geography [Accessed: 23 August 2018].

Best, Ulrich. 2009. "Critical Geography". In International Encyclopedia of Human Geography. Vol. 2. 345-357. Edited by Rob Kitchin, Nigel Thrift. Oxord: Elsevier. https://www.academia. edu/3620477/Critical_Geography._In_Kitchin_R_Thrift_N_eds_The_International Encyclopedia_of_Human_Geography_volume_2_pp._345-357._Oxford_Elsevier [Accessed: 23 August 2018].

Bieś-Srokosz, Paulina. 2018. "Legal Transplants in Administrative Law: Polish Experiences". In Law, Space and the Political: An East-West Perspective. 85-93. Edited by Paulina BieśSrokosz, Rafał Mańko, Jacek Srokosz. Częstochowa: Podobiński Publishing House.

Bocşan, Mircea-Dan. 2006. "L'oeuvre de codification - enjeu de la modernisation du droit roumain". In Modernisierung durch Transfer im 19. und frühen 20. Jahrhundert. 33-46. Edited by Tomasz Giaro. Frankfurt am Main: Vittorio Klostermann.

Cercel, Cosmin. 2018. Towards a Jurisprudence of State Communism: Law and the Failure of Revolution. London: Routledge.

Čepulo, Dalibor. 2006. "Building of the Modern Legal System in Croatia 1848-1918 in the Centre-periphery Perspective". In Modernisieuring durch Transfer im 19. und frühen 20. Jahrhundert. 47-91. Edited by Tomasz Giaro. Frankfurt am Main: Vittorio Klostermann.

Chmielnicki, Paweł. 2012. "Podejmowanie decyzji w warunkach prawnego i prawniczego potopu informacyjnego". Roczniki Administracji i Prawa. Teoria i Praktyka 12: 17-24.

Collins, Hugh. 1982. Marxism and Law. Oxford: Oxford University Press.

David, René. Brierley, John. 1968. Major Legal Systems in the World Today: An Introduction to the Comparative Study of Law. London: Stevens and Sons.

Diamant, Betinion. Vasile Luncean. 1986. "Note on the History of Romanian Law". Journal of Legal History 7(1): 98-101.

Fiedorczyk, Piotr. 2009. "Czechosłowacka droga do kodyfikacji prawa rodzinnego 19191949. Z dziejów współpracy z Polską". In Państwo, prawo, społeczeństwo $w$ dziejach Europy Środkowej. Księga jubileuszowa dedykowana Profesorowi Józefowi Ciagwie w siedemdziesięciolecie urodzin. 184-196. Edited by Adam Lityński. Katowice-Kraków: Wydawnictwo i Drukarnia Towarzystwo Słowaków w Polsce.

Fiedorczyk, Piotr. 2011. "Polski kodeks rodzinny z 1950 r. Czy przełom?” Zeszyty Prawnicze UKSW 11(2): 129-151.

Fiedorczyk, Piotr. 2012. "Počátky socialistického rodinného práva". In Vývoj soukromého práva na území českých zemí (I dil). 549-600. Edited by Ladislav Vojáček, Jaromír Tauchen, Karel Schelle. Brno: Masarykova Universita.

Fiedorczyk, Piotr. 2013. "Debata nad uchwaleniem polsko-czechosłowackiego prawa rodzinnego w czechosłowackim Zgromadzeniu Narodowym w 1949 r." Studia Iuridica Lublinensia 19: 131-141.

Gárdos-Orosz, Fruzsina. Bálasz Fekete. Eds. 2017. Central and Eastern European Socio-Political and Legal Transition Revisited. Frankfurt am Main: Peter Lang.

Helios, Joanna. Wioletta Jedlecka. Wspótczesne oblicza przemocy. Zagadnienia wybrane. Wrocław: Prawnicza i Ekonomiczna Biblioteka Cyfrowa.

Husa, Jakko. 2015. A New Introduction to Comparative Law. Oxford: Hart.

Jędrejek, Grzegorz. 2001. "Polski kodeks zobowiązań z 1933 roku. Powstanie, źródła, znaczenie dla europejskiego prawa obligacyjnego". Roczniki Nauk Prawnych 11(1): 47-68. 
Krzynówek, Jerzy. 2003. "Tradycje prawne Europy”. In Prawo polskie a prawo Unii Europejskiej. 23-34. Edited by Eugeniusz Piontek. Warszawa: Liber.

Kühn, Zdeněk. 2004. "Worlds Apart: Western and Central European Judicial Culture at the Onset of the European Enlargement". American Journal of Comparative Law 52(3): 531-567

Kühn, Zdeněk. 2011. The Judiciary in Central and Eastern Europe: Mechanical Jurisprudence in Transformation? Leiden-Boston: Martinus Nijhoff.

Mälksoo, Lauri. Wolfgang Benedek. Eds. 2017. Russia and the European Court of Human Rights: The Strasbourg Effect. Cambridge: Cambridge University Press.

Mańko, Rafał. 2007. "Is the Socialist Legal Tradition 'Dead and Buried'? The Continuity of Certain Elements of Socialist Legal Culture in Polish Civil Procedure". In Private Law and the Many Cultures of Europe. 83-103. Edited by Thomas Wilhelmsson. Alphen aan den Rijn: Kluwer Law International.

Mańko, Rafał. 2008. "Unifikacja europejskiego prawa prywatnego z perspektywy społeczeństwa polskiego: przyczynek do dyskusji”. Nowa Europa 2: 35-84.

Mańko, Rafał. 2012. "Resistance towards the Unfair Terms Directive in Poland: The Interaction between the Consumer Acquis and a Post-Socialist Legal Culture". In European Consumer Protection: Theory and Practice. 412-434. Edited by James Devenney, Mel Kenny. Cambridge: Cambridge University Press.

Mańko, Rafał. 2015. "The Cooperative Member's Proprietary Right to an Apartment: A Legal Survival of the Period of Actually Existing Socialism in Polish Private Law". Zeszyty Prawnicze 15(4): 147-176.

Mańko, Rafał. 2016a. "Transformacja ustrojowa a ciągłość instytucji prawnych - uwagi teoretyczne". Zeszyty Prawnicze 16(2): 5-35.

Mańko, Rafał. 2017a. "Legal Transfers in Europe Today: Still 'Modernisation Through Transfer'?” In Mutual Interaction Between Contemporary Systems and Branches of Law in European Countries. 139-155. Edited by Paulina Bieś-Srokosz, Jacek Srokosz, Ewelina ŻelaskoMakowska. Częstochowa: Podobiński Publishing House.

Mańko, Rafał. 2017b. "Prawo użytkowania wieczystego jako pozostałość po epoce realnego socjalizmu - ujęcie socjologicznoprawne”. Zeszyty Prawnicze 17(1): 35-63.

Mańko, Rafał. 2017c. "Symbolic Violence in Technocratic Law and Attempts at Its Overcoming: Politicisation Through Humanization?" Studia Erasmiana Wratislaviensia 11: 31-64.

Mańko, Rafał. 2018a. "Towards a Typology of Dimensions of the Continuity and Discontinuity of Law: The Perspective of Polish Private Law after the 1989 Transformation". Wroclaw Review of Law, Administration and Economics 6(2): 108-120.

Mańko, Rafał. 2018b. "Conference Report: 3rd International Workshop on Law and Ideology on the 'Rule of Law and the Politics of Conflict', Javakhishvili Tbilisi State University, Tbilisi, Georgia, 23-24 May 2016". Wroclaw Review of Law, Administration and Economics 6(2): 184-186.

Mańko, Rafał. 2018c. "XII Konferencja Central and Eastern European Network of Jurisprudence (CEENJ), Ryga, Łotwa, 14-16 września 2017 r.” Archiwum Filozofii Prawa i Filozofii Społecznej 18(3): 97-101.

Mańko, Rafał. Martin Škop. Marketa Štěpáníková. 2018. "Carving Out Central Europe as a Space of Legal Culture: A Way Out of Peripherality?" Wroclaw Review of Law, Administration and Economics 6(1): 4-28.

Mańko, Rafał. Wojciech Kauczor. Wojciech Zomerski. 2015. "Conference Report: 1st International Workshop on Law and Ideology (Wrocław, 29-30 May 2014)". Wrocław Review of Law, Administration and Economics 3(2): 84-88.

Medushevsky, Andrei. 2018. "Konstitutsionnaya retraditsionalizatsiya v vostochnoy Yevrope i Rossii”. Sravnitel'noye Konstitutsionoye Obozreniye 122(1): 13-22.

Merryman, John Henry. 1969. The Civil Law Tradition. Stanford: Stanford University Press. 
Micklitz, Hans-Wolfgang. 2015. "Prologue: The Westernisation of the East and the Easternisation of the West". In Central European Judges Under the European Influence: The Transformative Power of the EU Revisited. 1-12. Edited by Michal Bobek. Oxford: Hart Publishing/Bloomsbury. Nazmutdinov, Bulat. 2019. "Critical Dimensions of the 'Legal Culture' Approach: the Case of Classical Eurasianism and Eurasia's Legal Union”. Folia Iuridica 89: 81-93.

Philippopoulos-Mihalopoulos, Andreas. 2013. "Spatial Justice in the Lawscape". In Urban Interstices: The Aesthetics and Politics of the In-Between. 87-102. Edited by Andrea Brighenti. Surrey: Ashgate. Pirie, Gordon H. 1983. "On Spatial Justice". Environment and Planning 15: 465-473.

Rakoczy, Filip. 2015. "2nd International Workshop on Law And Ideology 'Memories of Struggles, Struggles of Memories', Sarajevo, 28-29 maja 2015”. Archiwum Filozofii Prawa i Filozofii Społecznej 11: 157-160.

Renner, Karl. 1975. The Institutions of Private Law and their Social Functions. London: Kegan \& Paul.

Rodak, Lidia. 2016. "Structural Violence and Its Gender Dimension in Polish Law". In Law and Critique in Central Europe: Questioning the Past, Resisting the Present. 131-153. Edited by Rafał Mańko, Cosmin Cercel, Adam Sulikowski. Oxford: Counterpress.

Sitek, Bronisław. 2008. “Od antropocentryzmu prawniczego do ekonomizacji prawa”. In Człowiek pomiędzy prawem a ekonomia w procesie integracji europejskiej. 515-523. Edited by Gaetano Dammacco, Bronisław Sitek, Oksana Cabaj. Olsztyn-Bari: Wydawnictwo Uniwersytetu Warmińsko-Mazurskiego.

Škop, Martin. 2016. "The Importance of Being a Linguist. Critical Legal Thought in Central Europe". In Law and Critique in Central Europe: Questioning the Past, Resisting the Present. 32-43. Edited by Rafał Mańko, Cosmin Cercel, Adam Sulikowski. Oxford: Counterpress.

Sulikowski, Adam. 2007. Wstęp do prawoznawstwa. Krótki kurs. Wałbrzych: Wałbrzyska Wyższa Szkoła Zarządzania i Przedsiębiorczości.

Szymaniec, Piotr. 2018. "Discussion About the Legal Identity of Central and Eastern Europe. 3rd Annual CEENELS Conference 'Legal Identities and Legal Traditions in CEE'”. Acta Universitatis Lodziensis. Folia Iuridica 85: 139-153.

Uzelac, Alan. 2010. “Survival of the Third Legal Tradition?” Supreme Court Law Review 49: 377-396.

Watson, Alan. 1993. Legal Transplants: An Approach to Comparative Law. Athens-London: University of Georgia Press.

Ziembiński, Zygmunt. 1980. Problemy podstawowe prawoznawstwa. Warszawa: PWN.

Ziętek, Magdalena. 2012. "Europejskie prawo konsumenckie jako wyraz technokratycznej koncepcji prawa umów”. In Kierunki rozwoju europejskiego prawa prywatnego. 275-291. Edited by Monika Jagielska, Ewa Rott-Pietrzyk, Aneta Wiewiórowska-Domagalska. Warszawa: C.H. Beck.

Zimmermann, Reinhard. 2006. "The German Civil Code and the Development of Private Law in Germany”. Oxford University Comparative Law Forum 1, available at: https://ouclf.iuscomp.org/ the-german-civil-code-and-the-development-of-private-law-in-germany [Accessed: 6 November 2019].

Zomerski, Wojciech. 2016. "Conference report: 1st International Conference of the Central European Network of Legal Scholars (CENELS) on 25 Years After the Transformation: Law and Legal Culture in Central and Eastern Europe. Between Continuity and Discontinuity', Masaryk University, Brno, Czech Republic, 16-17 April 2015”. Wroclaw Review of Law, Administration and Economics 4(2): 103-108.

Zomerski, Wojciech. 2018. "Conference Report: 2nd Annual Conference of the Central and Eastern European Network of Legal Scholars (CEENELS): 'An Uneasy Legacy: Remnants of Socialist Legal and Political Thinking in Central and Eastern Europe', Jagiellonian University, Faculty of Law and Administration, 7-8 January 2017". Wroclaw Review of Law, Administration and Economics 7(2): 83-85.

Zweigert, Konrad. Hein Kötz. 1996. Introduction to Comparative Law. Oxford: Clarendon Press. 